\title{
MODEL BIMBINGAN PERKEMBANGAN UNTUK MENINGKATKAN KECAKAPAN SOSIAL-PRIBADI ANAK BERBAKAT AKADEMIK
}

\author{
Rochmat Wahab \\ FIP Universitas Negeri Yogyakarta (e-mail: rochmat_wb@uny.ac.id)
}

\begin{abstract}
A Development Guidance Model to Improve Academically Gifted Children's Social-Personal Skills. This study intended to investigate the effectiveness of personal-social guidance programs for Academically Gifted Students (AGS). This study was a research and development study. The research subjects were 80 senior high students. The data were collected using an inventory and rating scales. The quantitative data were analyzed by the the descriptive and inferential statistical techniques, i.e. percentile, t-test and ANOVA, and the qualitative data by the descriptive technique. The results show that (1) the profile of personal-social skills among the AGS is very good, (2) the materials and implementation of the Personal-Social Guidance Program Guide on the basis of the Development Model is an appropriate alternative model that can increase the AGS's personal-social skills, (3) the Personal-Social Guidance Program Guide on the basis of the Developmental Model is empirically proven to be able to increase the AGS's personal-social skills.
\end{abstract}

Keywords: development guidance model, social-personal guidance, academically gifted students

\section{PENDAHULUAN}

Di Indonesia, secara kuantitatif anak berbakat akademik (ABA) sangatlah besa. Jika diasumsikan berdasarkan pendekatan statistik dikaitkan dengan definisi Marland Report (Piirto, 1994), jumlah anak berbakat sebanyak 3-5\% dari populasi. Namun, di antara mereka pada kenyataannya cenderung belum berprestasi optimal, terlebih-lebih di era krisis multi dimensional dewasa ini. Di sisi lain arus globalisasi sangat menghendaki kemampuan kompetitif setiap individu, tak terkecuali bangsa Indonesia. Untuk mengupayakan bangsa Indo- nesia di masa depan yang lebih prospektif, maka sangatlah diperlukan sistem pendidikan bermutu yang mampu membangun keunggulan (excellence). Untuk membangun keunggulan tersebut, bangsa Indonesia sangat bertumpu pada individu-individu berpotensi dan berprestasi cemerlang, yang salah satunya adalah ABA.

Berbagai upaya telah dilakukan dalam membangun keunggulan, di antaranya melakukan reformasi perundangundangan sistem pendidikan, manajemen pendidikan, orientasi kurikulum, dan model pembelajaran. Namun, pada 
kenyataannya, semuanya belumlah memadai. Berdasarkan pengalaman negara-negara maju, termasuk Amerika Serikat, layanan bimbingan dan konseling (BK) merupakan suatu jantung proses pendidikan yang ternyata mampu menunjukkan kontribusinya dalam mengakselerasi kemajuan pendidikan, yang pada gilirannya mampu membangun keunggulan (Silverman, 1993)

Walaupun secara fenomenal di sejumlah negara maju diyakini bahwa layanan BK sudah dipandang mampu memberikan kontribusi yang sangat berarti, pada kenyataannya layanan BK di semua jenjang pendidikan di Indonesia, khususnya pendidikan menengah, sebagai peletak kemampuan dasar, masih jauh dari yang diharapkan. Oleh karena itulah, sangat beralasan bahwa pencarian alternatif layanan $B K$, terutama untuk ABA pada SMA, merupakan suatu kebutuhan yang masih perlu terus diupayakan pemenuhannya.

Penelitian yang dilakukan ini didasarkan atas kebutuhan nyata di lapangan, yakni untuk mengetahui kinerja kecakapan sosial-pribadi ABA yang mengikuti program percepatan belajar (program akselerasi) pada sejumlah SMA di Indonesia. Hal ini dipandang penting, karena mereka sering mendapatkan sorotan dari masyarakat yang berkenaan dengan kecakapan sosial-pribadinya. Banyak anggota masyarakat yang masih menyangsikan efektivitas program akselerasi karena program tersebut diduga hanya menguntungkan aspek akademiknya saja dan tidak mampu membangun kecakapan sosial-pribadinya. Pandangan tersebut tidak sepenuhnya benar, karena banyak penelitian juga menunjukkan bahwa ABA juga memiliki kematangan sosial dan emosional yang baik. Hal ini diperkuat oleh Milgram (1991) bahwa "gifted learners as a group are characterized by more positive personal-social characteristics and fewer life difficulties than their less gifted peers."

Untuk semakin dapat membantu kehidupan sosial dan pribadi ABA, maka diupayakan suatu penelitian yang diarahkan untuk mengembangkan program bimbingan sosial-pribadi yang teruji secara empirik, yang dapat dibuktikan dengan kontribusinya terhadap peningkatan kecakapan sosialpribadinya.

Adapun fokus masalah penelitian ini adalah model bimbingan yang secara efektif dapat memberikan kesempatan seluas-luasnya bagi ABA pada SMA sehingga mereka dapat mengembangkan kecakapan sosial-pribadinya secara optimal. Secara konseptual, faktor non intelektual merupakan salah satu faktor utama yang dapat memfasilitasi pengembangan kemampuan akademik sehingga diharapkan melalui pengembangan kecakapan sosial-pribadi, ABA dapat terhindar dari kondisi berprestasi kurang dan dapat berkembang secara optimal.

Untuk lebih terfokusnya, maka secara rinci penelitian ini diharapkan dapat menjawab sejumlah masalah, di antaranya sebagai berikut.

- Bagaimanakah profil kecakapan sosial-pribadi ABA?

- Bagaimana kualitas Pedoman Umum Pengembangan Program Bimbingan Sosial-Pribadi berbasis Model Perkembangan bagi ABA? 
- Bagaimana efektivitas Program Bimbingan Sosial-Pribadi berbasis Model Perkembangan untuk ABA?

\section{METODE}

Penelitian ini menggunakan pendekatan penelitian dan perkembangan (research and development) sebagaimana yang dikembangkan oleh Borg and Gall (1989). Adapun subjek penelitiannya adalah ABA yang mengikuti Program Akselerasi di sejumlah SMAN, baik yang ada di Kota Bandung, maupun di Kota Yogyakarta. Subjek penelitian ini dikatagorikan berdasarkan jenis kelamin, latar belakang sosial ekonomi orang tua, dan letak huniannya. Variabel-variabel ini dipilih karena berdasarkan studi terdahulu variabel tersebut memiliki hubungan yang berarti terhadap kinerja akademik siswa berbakat akademik dan kecakapan sosial-pribadinya. Selain siswa, diharapkan juga para konselor dan guru menjadi subjek untuk diperoleh informasinya tentang kualitas dan kebermanfaatan Pedoman Umum Pengembangan Program Bimbingan Sosial-Pribadi berbasis Model Perkembangan yang dikembangkan.

Penentuan subjek penelitian untuk sekolah dilakukan berdasarkan teknik purposive random sampling, karena ditentukan sendiri oleh peneliti. Hal ini terjadi karena jumlah sekolah yang menyelenggarakan program pendidikan akselerasi untuk jenjang SMA terbatas. Demikian juga subjek penelitian ABA ditentukan melalui teknik purposive non random sampling, sehingga semua siswa siap dijadikan subjek penelitian untuk uji model terbatas. Sementara itu, penentuan subjek penelitian untuk konse- lor dan guru digunakan teknik random sampling, sehingga semua konselor dan guru berhak menjadi subjek penelitian.

Penentuan tempat uji coba model terbatas dilakukan di SMAN 3 Bandung dengan subjek penelitian sebanyak 8 orang siswa, satu orang konselor, dan dua orang guru; uji coba diperluas dilakukan di SMAN 1 dan 8 Yogyakarta dengan dengan subjek penelitian sebanyak 14 dan 12 orang siswa dan masing-masing satu orang konselor, dan dua orang guru; dan uji validasi model dilakukan di SMAN 1, 3, dan 8 Yogyakarta dengan dengan subjek penelitian sebanyak 12, 22, dan 12 orang siswa dan masing-masing satu orang konselor, dan dua orang guru. Untuk memperoleh data penelitian yang berkaitan dengan variabel kecakapan sosial-personal telah dikembangkan sejumlah alat pengumpul data yang terdiri atas satu inventori dan dua skala penilaian. Ketiga alat pengumpul data tersebut,di antaranya adalah (1) invontori kecakapan sosial-pribadi; (2) skala penilaian untuk implementasi program bimbingan sosial-pribadi; dan (3) skala penilaian untuk validasi pedoman umum pengembangan program bimbingan sosial-pribadi. Teknik analisis yang digunakan adalah teknik analisis statistik deskriptif berupa persentil dan teknik statistik inferensial, yaitu uji $t$, dan teknik analisis deskriptif kualitatif untuk menguji validasi model, baik berkenaan dengan program bimbingan sosial-pribadi berbasis model perkembangan maupun dampaknya terhadap kecakapan sosialpribadi ABA. 


\section{HASIL PENELITIAN}

Berdasarkan metodologi penelitian yang digunakan, maka hasil penelitian ini dikatagorikan menjadi dua hal penting, yaitu Hasil Pengembangan Model dan Hasil Uji Validasi Model.

\section{HASIL PENGEMBANGAN MODEL}

Berdasarkan prosedur penelitian yang dilalui pada tahap pertama diperoleh suatu Model Hipotetik tentang Pedoman Umum Pengembangan Program Bimbingan Sosial-Pribadi berbasis Model Perkembangan. Pada tahap kedua, ada dua kali uji coba model, yaitu uji coba model terbatas dan uji coba model diperluas. Adapun hasilnya adalah Pedoman Umum Pengembangan Program Bimbingan Sosial-Pribadi berbasis Model Perkembangan terdiri atas dua komponen utama, yaitu komponen struktural yang terdiri atas rasional, pernyataan filosofis, visi, tujuan, dan program bimbingan dalam perbandingan; dan komponen programatik yang terdiri atas domain layanan bimbingan, perencanaanindividual,layananresponsif, dukungansistem, dan tujuan program bimbingan sosial-pribadi berbasis perkembangan bagi anak berbakat. Di samping ituada bagian lain yang tidak kalah pentingnya, yaitu implementasi program dan fungsi, tanggung jawab, dan kualifikasi konselor yang dipersyaratkan untuk keberhasilan penerapan program.

Domain layanan bimbingan merupakan salah satu sub komponen yang menjadi sentral dari program bimbingan sosial-pribadi berbasis model perkembangan. Program bimbingan sosialpribadi difokuskan kepada pengembangan kecakapan yang berkenaan dengan aspek kesadaran diri-kolektif, perbaikan harga diri, membuat keputusan, mengelola waktu, resolusi konflik, respek terhadap perbedaan individu, dan keterampilan kepemimpinan.

\section{HASIL UJI VALIDASI MODEL}

Dalam bagian validasi model, ada beberapa hasil temuan yang perlu dikemukakan di sini sejalan dengan permasalahan penelitian, yaitu (a) profil kecakapan sosial-pribadi ABA SMAN Kota Yogyakarta; (b) materi dan implementasi pedoman umum pengembangan program bimbingan sosial-pribadi berbasis model perkembangan; dan (c) dampak program bimbingan sosial-pribadi berbasis model perkembangan terhadap peningkatan kecakapan sosialpribadi ABA berdasarkan jenis kelamin, status sosial-ekonomi orangtua, dan asal huniannya.

\section{Profil Kecakapan Sosial-Pribadi ABA SMAN Kota Yogyakarta}

Berdasarkan hasil uji validasi Model, maka dapat diperoleh profil kecakapan sosial-pribadi ABA SMAN Kota Yogyakarta sebagaimana dapat dilihat pada grafik berikut. 


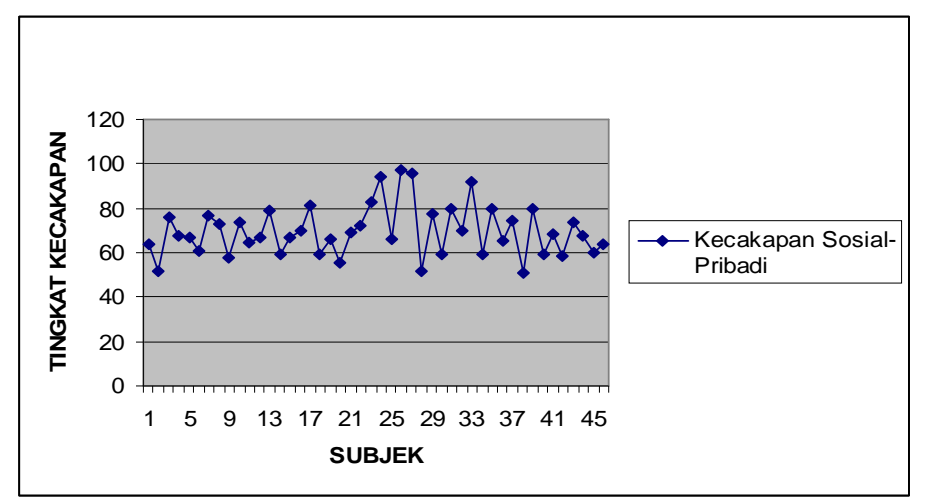

\section{Grafik 1. Profil Kecakapan Sosial-Pribadi ABA Berdasarkan Subjeknya}

Grafik1 menunjukkan bahwa sebagian besar ABA menunjukkan kecakapan sosial-pribadi dalam kategori baik, bahkan ada enam orang yang memiliki katagori baik sekali, karena kedudukannya berada di atas prosentase 60. Dengan demikian, dapat memperjelas bahwa tidaklah sepenuhnya benar, jika ABA cenderung memiliki masalah sosialpribadi, ketika mereka dilayani pendidikannya melalui program akselerasi. Sebaliknya, di antara 46 siswa, hanya delapan siswa yang me- miliki kecakapan sosial-pribadi dalam katagori sedang. Oleh karena itu, penampilan kecakapan sosialpribadi ABA masih cukup membanggakan karena mereka tidak terlalu membebani masalah bagi orang lain. Bahkan, ada kesan yang sangat positif bahwa dengan berkumpulnya mereka dalam suatu program, di antara mereka muncul sikap dan prilaku yang saling kooperatif karena mereka sering dihadapkan dengan tantangan yang relatif sama.

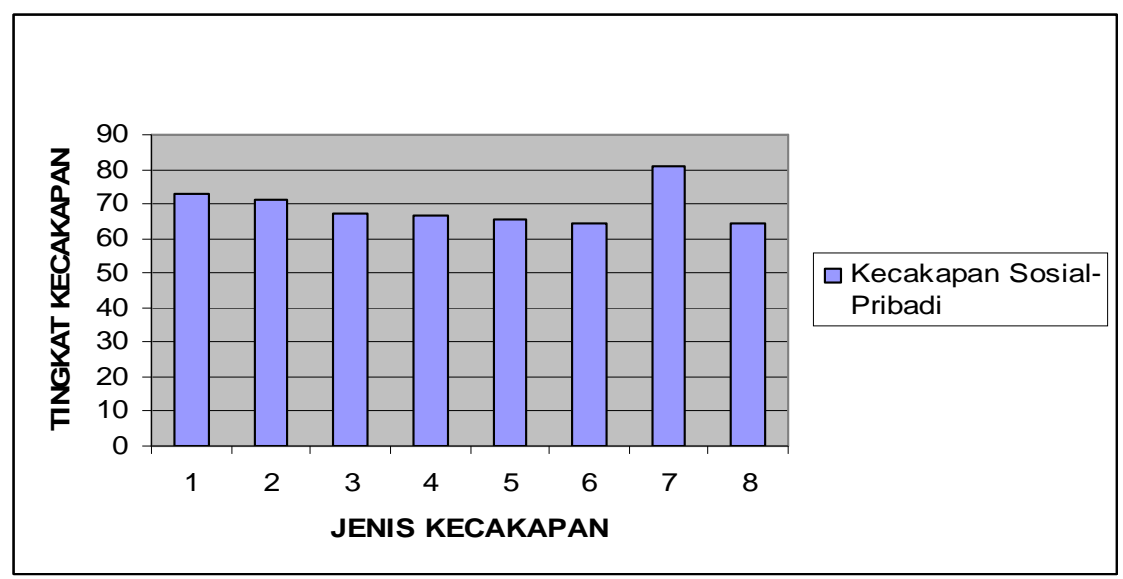

Grafik 2. Profil Kecakapan Sosial-Pribadi ABA Berdasarkan Jenis Kecakapannya

Model Bimbingan Perkembangan untuk Meningkatkan Kecakapan Sosial-Pribadi 
Grafik 2 menunjukkan ABA SMAN Kota Yogyakarta cenderung memiliki kecakapan sosial-pribadi yang baik. Yang menarik adalah ada fenomena yang sangat menonjol di bidang respek terhadap perbedaan inidvidu dan perilaku kooperatif (7), yang disusul dengan kesadaran diri (1), dan harga diri yang tinggi (2). Hal ini mengindikasi- kan bahwa mereka sangat familiar dengan hidup bersama dengan orang lain tanpa membedakan latar belakang agama, suku, golongan, dan sebagainya. Yang demikian sangat mungkin karena mereka berada di suatu daerah kecil yang menjadi tempat bertemunya manusia yang sangat beragam.

\section{Tabel 1. Rerata Dan Simpangan Baku Kecakapan Sosial-Pribadi ABA}

\begin{tabular}{lccccc}
\hline Kecakapan & N & Minimum & Maximum & Rerata & $\begin{array}{c}\text { Standar } \\
\text { Deviasi }\end{array}$ \\
\hline Kesadaran diri & 46 & 49.00 & 92.00 & 68.4130 & 10.87214 \\
Harga diri (Slef-esteem) & 46 & 40.00 & 72.00 & 51.3696 & 8.02319 \\
Membuat keputusan & 46 & 21.00 & 44.00 & 29.4783 & 5.88686 \\
Mengelola waktu & 46 & 27.00 & 49.00 & 34.7609 & 6.07064 \\
Resolusi konflik & 46 & 24.00 & 72.00 & 47.1957 & 10.21898 \\
Keterampilan & 46 & 10.00 & 52.00 & 33.3261 & 9.75717 \\
komunikasi & & & & & \\
Respek thd perbed. & 46 & 38.00 & 59.00 & 48.5652 & 6.07235 \\
Individu & & & & & \\
Kepemimpinan & 46 & 28.00 & 75.00 & 48.8043 & 11.98262 \\
Total & 46 & 266.00 & 505.00 & 361.9130 & 60.37396 \\
\hline
\end{tabular}

Grafik 1 dan Tabel 1 menunjukkan bahwa tingginya respek terhadap perbedaan individu ABA SMAN Kota Yogyakarta sangatlah dipengaruhi oleh kecilnya standar deviasinya. Walaupun standar deviasi kecakapan sosial-personal membuat keputusan itu lebih rendah, tetapi besarnya standar deviasi respek terhadap perbedaan individu lebih bermakna karena angka maksimum dan minimumnya jauh lebih tinggi daripada kecakapan membuat keputusan. Sebaliknya, rendahnya posisi keterampilan kepemimpinan ABA SMAN Kota Yogyakarta juga tidak dapat dipungkiri disebabkan oleh besarnya angka standar deviasi di balik reratanya.
Berdasarkan deskripsi profil sebelumnya, maka dapat ditasirkan bahwa kecakapan sosial-pribadi ABA SMAN Kota Yogyakarta pada kenyataannya sangat beragam, walaupun ada kecenderungan mereka memiliki tingkat pada setiap jenis kecakapannya relatif sama karena mereka menunjukkan kecakapan yang masih berada pada katagori baik dan di atasnya, yaitu katagori sangat baik. Jika dilihat kecenderungan kecakapan yang dimiliki, mereka menunjukkan penonjolan yang sangat berarti pada kecakapan respek terhadap perbedaan individu dan berperilaku kooperatif, yang merupakan kecakapan pada umumnya sangat dikhawatirkan 
oleh kebanyakan orang terhadap kehadiran ABA yang mendapat perlakuan melalui program percepatan belajar. Dengan potensi kecakapan tersebut diharapkan dapat memperbaiki citra mereka di tengah-tengah masyarakat bahwa mereka cenderung ditengarai sebagai individu yang lebih suka hidup sendiri dan sulit bergaul dengan orang lainnya.

\section{Materi dan Implementasi Pedoman Umum Pengembangan Program Bim- bingan Sosial-Pribadi Yang Berbasis Model Perkembangan}

Untuk menguji validasi Program Bimbingan Sosial-Pribadi berbasis model perkembangan, maka dilakukan evaluasi terhadap materi dan implementasinya, yang hasilnya dapat diperoleh sebagai berikut.

- Materi Program bimbingan sosialpribadi berbasis model perkembangan

Berdasarkan reviu yang dilakukan oleh tiga konselor terhadap materi PedomanUmum Pengembangan Program Bimbingan Sosial-Pribadi Berbasis Model Perkembangan menunjukkan bahwa isi pedoman umum tersebut dikatagorikan baik atau memadai, bahkan untuk beberapa materi menunjukkan sangat baik atau sangat memadai, bahkan tak ada materi satu pun yang mengindikasikan sedang, apalagi sangat kurang baik atau memadai. Artinya, bahwa substansi pedoman umum yang telah dikembangkan dapat dijadikan salah satu rujukan untuk memberikan layanan bimbingan kepada ABA, terutama untuk pengembangan keca- kapan sosial-pribadinya. Bahkan konselor melalui responnya yang terbuka, bahwa pedoman umum tersebut dapat dijadikan rujukan dalam memberikan layanan yang efektif dan produktif karena isinya dapat memberikan kepastian arah dalam memfasilitasi perkembangan ABA sehingga mereka mampu menentukan target dalam mencapai tujuan hidup. Yang penting juga diperhatikan di antara mereka berkeyakinan bahwa pedoman pada batas-batas tertentu dapat digunakan untuk siswa pada umumnya.

- Implementasi Pedoman Umum Pengembangan Program Bimbingan Sosial-Pribadi Berbasis Model Perkembangan

Untuk mengetahui kondisi implementasi model diperluas, maka diperoleh hasil penilaian dari subjek penelitian yang dapat dilihat pada Tabel 2 . berikut.

Tabel 2 memperlihatkan bahwa implementasi Program Sosial-Pribadi Berbasis Model Perkembangan sudah berjalan relatif efektif karena hampir sebagian besar aspek implementasi mendapat penilaian baik dan baik sekali, terutama kemanfaatan materi tentang memahami diri dan mengelola waktu, penampilan konselor, dan tempat bimbingan. Namun di balik itu sungguh menarik, bahwa jumlah subjek yang memberikan penilaian kurang baik untuk kemanfaatan materi justru pada aspek yang sama, yaitu tentang memahami diri dan mengelola waktu, walaupun tidak ada yang memberikan penilaian yang kurang sekali. 
Di samping uraian di atas, secara bebas siswa memberikan catatan yang sangat variatif tentang kesannya terhadap implementasi model, di antaranya: (a) adanya permainan (games) yang melibatkan kekompakan dengan tetap mampu mengembangkan kreativitas; (b) kegiatan yang diciptakan menarik; (c) siswa semakin mengenal, mengerti, dan memahami kepribadian, potensi (kekuatan) dan kelemahan diri sendiri serta orang lain (teman) sehingga menambah semangat dalam hidupnya; (d) materi tentang manajemen waktu, sehingga dapat mengatur waktu yang seefisien dan seefektif mungkin; (e) memungkinkan untuk bisa berkumpul bersama-sama teman; (f) setiap orang mendapat kesempatan mengungkapkan pendapat dan pemikirannya; dan (g) lebih bisa memahami perbedaan yang ada dan dapat lebih menghargai teman lain. Di antara semua kesan tersebut di atas, yang merupakan kesan paling mendalam terjadi pada sebagian besar siswa setelah melalui bimbingan adalah mereka lebih banyak mengenal, memahami, mengerti diri sendiri dan keragaman yang ada pada orang lain, sehingga memudahkan mereka untuk saling mengerti dan respek yang menghasilkan hubungan dan komunikasi sehat di antara mereka sehingga terbangun kebersamaan, kerukunan, kekompakan, dan keakraban dalam kehidupan sehari-hari.

Berdasarkan reviu atau yang dilakukan terhadap materi dan implementasi program bimbingan sosial-pribadi berbasis model perkembangan untuk meningkatan kecakapan sosial-pribadi ABA, maka program bimbingan sosialpribadi berbasis model perkembangan ini dapat ditimbang sebagai suatu pedoman yang memadai untuk memberikan layanan bimbingan sosial-pribadi bagi ABA. Keyakinan ini secara empirik didukung oleh temuan yang menunjukkan bahwa sebagian besar aspek materi Program bimbingan sosial-pribadi berbasis model perkembangan memiliki penilaian baik dan baik sekali, terutama dikaitkan dengan persiapan dan manfaat dari materi yang didapatkan.

Selain daripada itu penampilan implementasi Program bimbingan sosialpribadi berbasis model perkembangan juga menunjukkan kecenderungan pada katagori baik dan sangat baik, terutama dalam penggunaan metode, aktivitas, dan penampilan konselor, walaupun sebagian kecil masih ada kekurangan pada persiapan, kemanfaatan materi mengelola waktu, ketersediaan alat, waktu, dan tempat bimbingan.

\section{EFEKTIVITAS PROGRAM BIM- BINGAN SOSIAL-PRIBADI BERBA- SIS MODEL PERKEMBANGAN}

Setelah implementasi program bimbingan sosial-pribadi berbasis model perkembangan terhadap peningkatan kecakapan sosial-pribadi, maka dapat dilihat profilenya, baik kondisi pra dan pasca perlakuan berdasarkan subjeknya maupun jenis kecakapan sosial-pribadinya. 
Tabel 2. Kualitas Implementasi Program Bimbingan Sosial-Pribadi Berbasis Model Perkembangan

\begin{tabular}{|c|c|c|c|c|c|c|c|c|c|c|c|}
\hline \multirow[t]{2}{*}{ No. } & \multirow[t]{2}{*}{ Aspek } & \multicolumn{2}{|r|}{$\mathrm{A}$} & \multicolumn{2}{|c|}{$\mathrm{B}$} & \multicolumn{2}{|c|}{$\mathrm{C}$} & \multicolumn{2}{|r|}{$\mathrm{D}$} & \multicolumn{2}{|c|}{$\mathrm{E}$} \\
\hline & & $\mathrm{f}$ & $\%$ & $f$ & $\%$ & $\mathrm{f}$ & $\%$ & $\mathrm{~F}$ & $\%$ & $\mathrm{f}$ & $\%$ \\
\hline A. & PERSIAPAN & 2 & 7.69 & 13 & 50.00 & 11 & 42.31 & 0 & .00 & 0 & .00 \\
\hline B. & $\begin{array}{l}\text { PENYELENGGARAAN } \\
\text { KEGIATAN BIMBINGAN }\end{array}$ & 3 & 11.54 & 22 & 84.62 & 1 & 3.85 & 0 & .00 & 0 & .00 \\
\hline C. & KEMANFAATAN MATERI: & & & & & & & & & & \\
\hline & 1. Pemahaman diri & 5 & 19.23 & 15 & 57.69 & 2 & 7.69 & 4 & 15.38 & 0 & .00 \\
\hline & 2. Perbaikan Harga Diri & 1 & 3.85 & 17 & 65.38 & 8 & 30.77 & 0 & .00 & 0 & .00 \\
\hline & $\begin{array}{l}\text { 3. Kemampuan Membuat } \\
\text { Keputusan }\end{array}$ & 0 & .00 & 16 & 61.54 & 9 & 34.62 & 1 & 3.85 & 0 & .00 \\
\hline & $\begin{array}{l}\text { 4. Kemampuan Mengelola } \\
\text { Waktu }\end{array}$ & 4 & 15.38 & 11 & 42.31 & 8 & 30.77 & 3 & 11.54 & 0 & .00 \\
\hline & 5. Resolusi Konflik & 0 & .00 & 13 & 50.00 & 11 & 42.31 & 2 & 7.69 & 0 & .00 \\
\hline & 6. Keterampilan Berkomunikasi & 2 & 7.69 & 17 & 65.38 & 7 & 26.92 & 0 & .00 & 0 & .00 \\
\hline & $\begin{array}{l}\text { 7. Respek terhadap Perbedaan } \\
\text { Individu }\end{array}$ & 5 & 19.23 & 16 & 61.54 & 4 & 15.38 & 1 & 3.85 & 0 & .00 \\
\hline & 8. Keterampilan Kepemimpinan & 0 & .00 & 11 & 42.31 & 13 & 50.00 & 2 & 7.69 & 0 & .00 \\
\hline D. & METODE/TEKNIK BIMBINGAN & 3 & 11.54 & 15 & 57.69 & 7 & 26.92 & 1 & 3.85 & 0 & .00 \\
\hline E. & PROSEDUR BIMBINGAN & 2 & 7.69 & 17 & 65.38 & 7 & 26.92 & 0 & .00 & 0 & .00 \\
\hline F. & AKTIVITAS BIMBINGAN & 2 & 7.69 & 19 & 73.08 & 5 & 19.23 & 0 & .00 & 0 & .00 \\
\hline G. & REFLEKSI & 3 & 11.54 & 16 & 61.54 & 7 & 26.92 & 0 & .00 & 0 & .00 \\
\hline $\mathrm{H}$. & $\begin{array}{l}\text { PENAMPILAN } \\
\text { PEMBIMBING/KONSELOR }\end{array}$ & 4 & 15.38 & 18 & 69.23 & 4 & 15.38 & 0 & .00 & 0 & .00 \\
\hline I. & ALATPERLENGKAPAN & 2 & 7.69 & 12 & 46.15 & 10 & 38.46 & 2 & 7.69 & 0 & .00 \\
\hline $\mathrm{J}$. & $\begin{array}{l}\text { WAKTU KEGIATAN } \\
\text { BIMBINGAN }\end{array}$ & 2 & 7.69 & 9 & 34.62 & 11 & 42.31 & 4 & 15.38 & 0 & .00 \\
\hline K. & $\begin{array}{l}\text { TEMPAT KEGIATAN } \\
\text { BIMBINGAN }\end{array}$ & 7 & 26.92 & 12 & 46.15 & 7 & 26.92 & 0 & .00 & 0 & .00 \\
\hline
\end{tabular}

Keterangan

A = Sangat Baik/Sangat Memadai

$\mathrm{D}=$ Kurang Baik/Kurang Memadai

$\mathrm{B}=$ Baik/Memadai

$\mathrm{C}=$ Sedang

$\mathrm{E}=$ Sangat Kurang Baik/Sangat Kurang Memadai 
Profil Kecakapan Sosial-Pribadi ABA SMAN Kota Yogyakarta Pra dan Pasca Perlakuan Berdasarkan Subjeknya

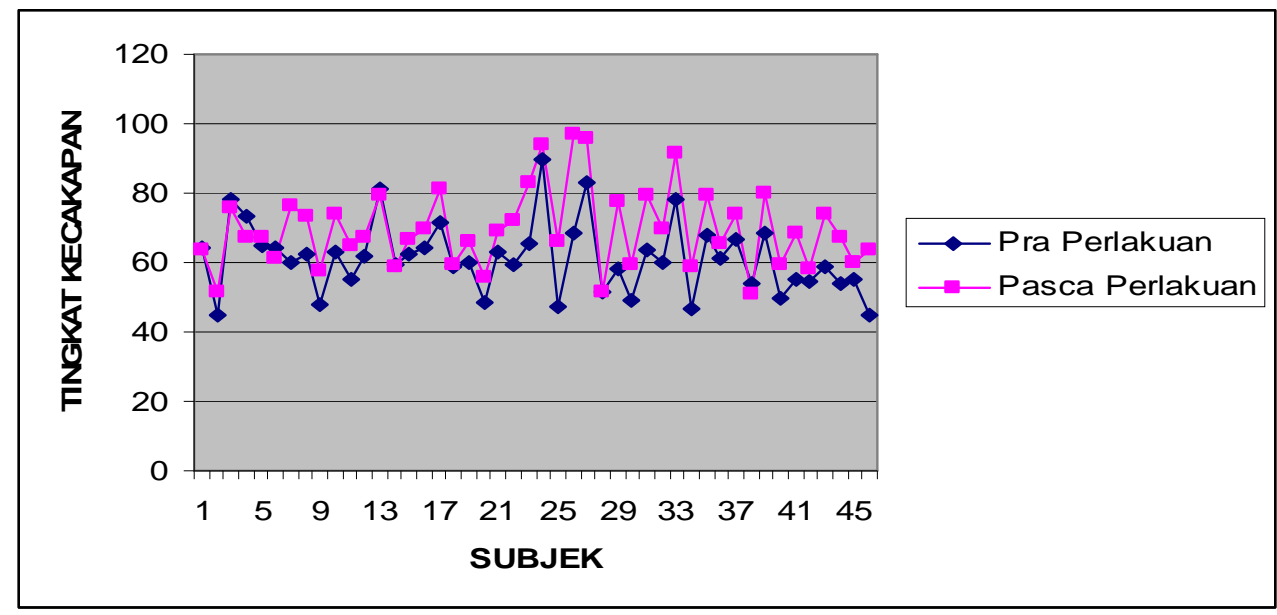

Grafik 3. Profil Kecakapan Sosial-Pribadi ABA

Grafik 3 menunjukkan adanya kecenderungan bahwa sebagian besar dari 46 ABA memiliki kecakapan sosialpersonal yang baik dan memadai. Selain daripada itu, setelah mendapatkan perlakuan bahwa ABA menunjukkan kenaikan kecakapan, terutama yang mengalami kenaikan yang berarti, misalnya subjek ke 7, 22, 23, 26, 31. 43, dan 46. Di samping itu, ada sejumlah enam orang yang menunjukkan penurunan kecakapan, walaupun penurunannya hanya menunjukkan angka yang tipis.
PROFIL KECAKAPAN SOSIAL-PRIBADI ABA SMAN KOTA YOGYAKARTA

Grafik 4 menunjukkan bahwa kecakapan respek terhadap perbedaan individu paling menonojol. Hal ini mengindikasikan bahwa ABA kota Yogyakarta cenderung memiliki sikap toleransi dan respek yang tinggi terhadap suku dan bangsa manapun. Selain itu, menunjukkan bahwa hampir semua kecakapan mangalami peningkatan skor setelah melalui implementasi model bimbingan. Tidak satupun kecakapan yang mengalami penurunan. Dengan demikian, secara selintas program bimbingan yang dikembangkan menunjukkan kontribusinya bagi peningkatan kecakapan sosial-pribadi. 


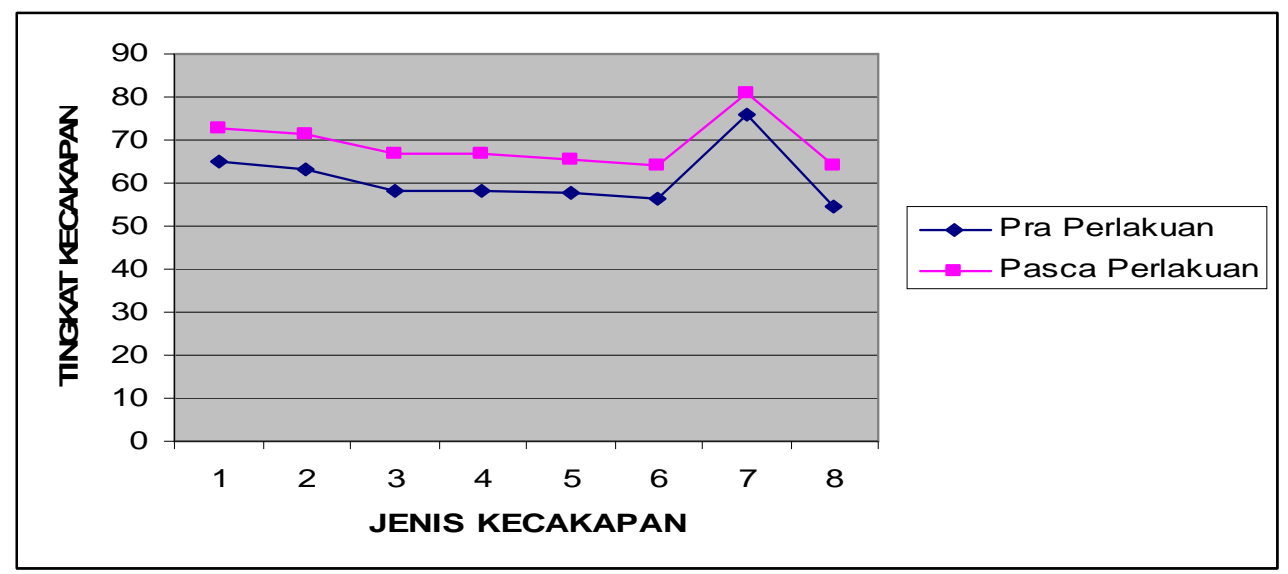

Grafik 4. Profil Kecakapan Sosial-Pribadi ABA SMAN Kota Yogyakarta Pra dan Pasca Perlakuan Berdasarkan Jenis Kecakapannya

Berdasarkan disain eksperimen, untuk menguji efektivitas program bimbingan sosial-pribadi berbasis model perkembangan ada dua pola uji perbedaan dua rata-rata, yaitu (1) uji dua perbedaan rata-rata pre test dan post test antara kelompok eksperimen dan kelompok kontrol; (2) uji dua perbedaan rata-rata pre test antara kelompok eksperimen dan kelompok kontrol dan rata-rata post test antara kelompok eksperimen dan kelompok kontrol. Untuk mendapatkan gambaran hasil yang lebih akurat, maka untuk menguji efektivitas program bimbingan sosial-pri- badi berbasis model perkembangan, dipilih pola (1) dengan membedakan suatu kelompok dengan dirinya sendiri antara hasil pre test dan post test-nya.

Setelah dipenuhi ketiga persyaratan dalam analisis tes parametrik, yaitu representaisivitas sampel, normalitas distribusi, dan homoginitas variansi, selanjutnya dapat dilakukan analisis dengan teknik statistik inferensial yang menggunakan rumus Uji t.

Berdasarkan perhitungan yang dilakukan dalam lampiran, dapat diperoleh hasil sebagaimana yang tercantum dalam tabel berikut ini.

Tabel 2. Hasil Uji t antara Pre Test dan Post Test Kelompok Eksperimen dan Kontrol

\begin{tabular}{lcrcccc}
\hline Variabel & N & Rata-rata & Simp. Baku & T & dk & Sign. \\
\hline Pret-Test Kel. Eksp. & 46 & 318,858 & 53,432 & $-6,191$ & 45 & 0,000 \\
Post-Test Kel. Eksp. & & 361,913 & 60,374 & & & \\
Pre-Test Kel. Kontrol & 46 & 348,978 & 50,699 & $-2,595$ & 45 & 0,013 \\
Post-Test Kel. Kontrol & & 353,783 & 52,917 & & & \\
\hline
\end{tabular}


Tabel 2 menjelaskan bahwa implementasi program bimbingan sosial-pribadimenunjukkan perbedaan antara hasil tes awal kecakapan sosial-pribadi terhadap 46 orang dengan skor rata-rata pada kelompok eksperimen 318,858 dan standar deviasinya 53,432 dan tes akhir kecakapan sosial-pribadinya dengan skor rata-rata 361,913 dan standar deviasinya 60,374. Dari hasil ini diperoleh $\mathrm{t}=-6,191$ yang dengan dk 45 menunjukkan hasil yang sangat signifikan $(p=0,000)$. Sementara itu, dari hasil perhitungan diperoleh hasil tes awal kelompok kontrol dengan rata-rata 348,978 dan standar deviasinya 50,699 dan hasil tes akhirnya 353, 783 dan standar deviasinya 52,917. Dari hasil ini diperoleh $\mathrm{t}=-2,595$ yang dengan $\mathrm{dk} 45$ menunjukkan hasil signifikan ( $\mathrm{p}=$ 0,013). Hal ini lebih diyakinkan lagi bahwa perolehan (gains) yang didapatkan dalam kelompok perlakuan (treatment group) $=43,055$ yang jauh lebih tinggi daripada perolehan (gains) yang didapatkan oleh kelompok control (control group) $=4,805$.

Berdasarkan hasil analisis, dapat dinyatakan bahwa program bimbingan sosial-pribadi berbasis model perkembangan terbukti memberikan sumbangan sangat signifikan terhadap peningkatan kecakapan sosial-pribadi ABA. 
PEDOMAN UMUM PENGEMBANGAN PROGRAM BIMBINGAN SOSIALPRIBADI BERBASIS MODEL PERKEMBANGAN

\section{BAGIAN PERTAMA}

\section{A. Komponen Struktural:}

Komponen ini berisi rasionale, pernyataan filosofi, visi, tujuan bimbingan dan konseling, dan program bimbingan dalam perbandingan

\section{B. Komponen Programatik:}

Komponen ini terdiri atas program bimbingan, perencanaan individual, layanan responsif, dukungan system, dan tujuan Pedoman Umum Pengembangan Program Sosial-Pribadi Berbasis Model Perkembangan bagi ABA.

\section{Komponen-komponen lain:}

Komponen ini terdiri atas implementasi program, fungsi dan tanggung jawab konselor, serta kualifikasi konselor

\section{A. Modul Inti:}

\section{BAGIAN KEDUA}

Pada dasarnya modul inti terdiri atas beberapa aspek yang terdiri di antaranya:

1. Pengantar: Bagian ini menjelaskan dasar pemikiran diperlukannya suatu bentuk bimbingan perkembangan yang berkaitan dengan kecakapan sosialpribadi tertentu, terutama untuk ABA yang memiliki karakteristik dan kebutuhan tertentu pula, sehingga bimbingan perkembangan bermanfaat bagi pengembangan ABA secara optimal.

2. Tujuan: Bimbingan Perkembangan dimaksudkan untuk meningkatkan kecakapan sosial-pribadi ABA secara optimal, sehingga mereka dapat menjadi individu yang mandiri dan bermanfaat bagi kehidupan masyarakat dan kemanusiaan.

3. Materi : Bimbingan Perkembangan bidang sosial-pribadi lebih difokuskan pada kecakapan sosial-pribadi yang di antaranya terdiri atas (1) pemantapan pemahaman diri, (2) perbaikan harga diri (self-esteem), (3) kemampuan membuat keputusan, (4) kemampuan mengelola waktu, (5) resolusi konflik, (6) keterampilan berkomunikasi, (7) respek terhadaap perbedaan individu dan perilaku kooperatif, dan (8) keterampilan kepemimpinan. 
4. Prosedur dan Refleksi : Prosedur kegiatan bimbingan diawali dengan mengantarkan dan menjelaskan materi seperlunya, dilanjutkan dengan aktivitas bimbingan secara kolektif dengan memberikan kebebasan kepada mereka untuk memilih kelompoknya masing-masing yang dilanjutkan dengan mengerjakan kegiatan bimbingan yang telah dirancang dan diakhiri dengan refleksi yang penekanannya pada mencari berbagai pelajaran yang berarti, yang dapat diambil dari kegiatan yang baru berlangsung, terutama dikaitkan dengan substansi yang menjadi tema kegiatan bimbingan.

5. Metode, Media, dan Setting: Metode yang digunakan dalam konteks ini adalah bimbingan kelompok dengan penekanan pada life skills training. Media dan alat bimbingan perlu disesuaikan dengan materi. Umumnya format, kertas manila, atau benda-benda lain (baik asli maupun tiruan) yang dianggap relevan dengan materi yang menjadi fokus layanan bimbingan.

6.. Waktu dan tempat: Rentangan waktu yang diperlukan untuk terselenggaranya kegiatan bimbingan setiap sesi sekitar 90 menit. Sedangkan tempat yang cocok untuk kegiatan bimbingan perlu disepakati antara siswa dan konselor sekolah, apakah in-door atau out-door), sehingga diharapkan dapat menjamin kenyamanan selama layangan bimbingan berlangsung.

\section{B. Modul Latihan}

Modul Latihan mengandung format yang harus diisi dan petunjuk kegiatan siswa dihararapkan mampu manfasilitasi keberlangsungan suatu kegiatan bimbingan secara lancar dan produktif.

\section{Bagan 1 \\ Program Bimbingan Sosial-Pribadi \\ Berbasis Model Perkembangan \\ (Hasil Uji Validasi)}

d. Model Akhir Program Bimbingan Perkembangan

Setelah dilakukan validasi Pedoman Umum Pengembangan Program Sosial-Pribadi Berbasis Model Perkembangan, maka dilakukan revisi yang secukupnya, sehingga diperoleh Model Akhir Program Bimbingan Sosial-Pribadi bagi ABA pada Sekolah Menengah Atas. Kiranya perlu diketahui bahwa penelitian ini untuk sementara hanya dibatasi sampai pada tahap ini, tidak sampai pada tahap sosialisasi atau difusi. Namun, sampai batas tertentu dengan segala keterbatasan akan dilakukan sosialasi, misalnya publikasi hasil penelitian

\section{PEMBAHASAN}

Di antara rumusan kesimpulan sebelumnya nampak hal-hal yang memerlukan pembahasan. Adapun pembahasan hasil penelitian dapat bersifat 
konseptual-teoretik-logik, empirik-teknis operasional, dan atau metodologik.

\section{PROFIL KECAKAPAN SOSIAL-PRI-} BADI ABA

Hasil penelitian menyatakan bahwa profil kecakapan sosial-pribadi ABA menunjukkan katagori memadai, baik pada pra perlakuan maupun pasca perlakuan. Pembicaraan tentang aspek sosial-pribadi merupakan pembicaraan yang sangat menarik dan berarti bagi semua pihak termasuk juga bagi ABA, karena aspek sosial-pribadi sangat erat kaitannya dengan aspek kehidupan manusia.

Banyak sekali komentar bahwa siapapun yang telah meraih prestasi, apakah bidang akademik maupun karir, belum dapat menjamin yang bersangkutan dapat meraih keberhasilan yang hakiki, sebelum dia mampu menguasai dirinya dan kehadirannya diterima secara sosial oleh lingkungannya. Demikian juga berlaku bagi ABA, bahwa mereka belumlah dapat dijamin kesuksesan hidupnya hanya dengan bermodal keunggulan potensi dan prestasi akademiknya. Dengan begitu, mereka tetap masih memerlukan upaya yang sungguh-sungguh untuk meraih keberhasilan hidupnya.

Menyadari akan kondisi tersebut sangatlah wajar jika kebanyakan orang memiliki kekhawatiran yang tinggi terhadap kemungkinan munculnya perilaku arogansi di balik keberbakatan yang dimiliki oleh ABA. Kekhawatiran itu boleh jadi berlebihan sehingga mereka relatif enggan untuk memberikan pelayanan pendidikan yang sesuai dengan kemampuan potensialnya. Akhir- nya, masyarakat banyak yang "memaksa" mereka untuk mengikuti pendidikan secara regular dengan pelayanan yang regular juga (Davis and Rimm, 1989). Padahal perlakuan yang demikian justru bertentangan dengan prinsip demokratisasi pendidikan dan prinsip pedagogis. Artinya, bahwa mereka seharusnya mendapatkan pelayanan pendidikan sesuai dengan potensi dan kebutuhannya.

Kondisi di lapangan yang demikianlah sebenarnya yang menjadi titik awal munculnya permasalahan yang mengundang untuk diteliti. Apa benar bahwa ABA memiliki kecakapan sosialpribadi yang kurang positif, khususnya yang mengikuti program akselerasi. Secara empirik bahwa pada ketiga kelompok subjek penelitian, baik pada tahap awal untuk ujicoba model (pedoman) terbatas, pada tahap kedua untuk uji coba model (pedoman) diperluas, maupun pada tahap uji validasi, mereka cenderung menunjukkan kecakapan personal sosial dalam katagori baik, bahkan ada beberapa yang baik sekali, walau ada juga yang katagori sedang, tetapi tidak satu pun yang berada pada katagori kurang dan kurang sekali. Temuan penelitian ini juga semakin mengukuhkan temuan yang secara konsisten dalam waktu yang panjang oleh Janos \& Robinson (1985); Tannembanum, (1983); Terman, (1923); Terman and Oden $(1947,1959)$ yang dikutip oleh Milgram (1991) yang menyatakan bahwa gifted learners as a group are characterized by more positive personal-social characteristics and fewer life difficulties than their les gifted peers... Only a small pro- 
portion of gifed children have psychological adjustmen problems.

Konsisten dengan apa yang menjadi sorotan masyarakat bahwa ABA yang dilayani dengan kelas khusus cenderung menjadi elit dan miskin sosialnya (Colangelo and Davis, 1991). Padahal, penelitian ini memberikan bukti bahwa justru di antara delapan kecakapan sosial-pribadi, kecakapan respek terhadap perbedaan individu dan berperilaku kooperatif menunjukkan angka yang paling menonjol di antara kecakapan lainnya yang disusul dengan keterampilan kepemimpinan.

PROGRAM BIMBINGAN SOSIALPRIBADI BERBASIS MODEL PERKEMBANGAN EFEKTIF MENINGKATKAN KECAKAPAN SOSIALPRIBADI ABA

Program bimbingan sosial-pribadi berbasis model perkembangan merupakan suatu alternatif yang efektif untuk meningkatkan kecakapan sosial-pribadi ABA. Pada dasarnya kecakapan sosialpribadi ABA itu tidaklah meningkat dengan sendirinya atau berlangsung secara alamiah, melainkan membutuhkan berbagai upaya yang sistematis dan kontinyu. Banyak cara yang dapat dilakukan untuk meningkatkan kecakapan sosial-pribadi. Namun, tidak semua cara itu memiliki efektivitas yang sama.

Salah satu cara yang memiliki efektivitas tinggi untuk meningkatkan kecakapan sosial-pribadi adalah program bimbingan sosial-pribadi berbasis model perkembangan. Setidak-tidaknya, karya Bowers dan Hatch (2002) melalui The National Model for School Counseling
Program menjadi rujukan utama program ini menyatakan bahwa school counseling program is comprehensive in scope, preventive in design, and developmental in nature. Artinya, bahwa skopa model ini sangat komprehensif karena dialamatkan kepada seluruh jenjang dan seluruh domain, termasuk di dalamnya domain sosial-pribadi. Dengan kata lain, program ini tidak hanya diorientasikan untuk mengantarkan anak berhasil sekolahnya saja, melainkan juga menjadikan mereka mandiri dan bermanfaat bagi masyarakat. Program ini mendorong konselor untuk lebih mengutamakan fungsi preventif dan proaktif, di samping remedial, sehingga konselor sekolah sangat dituntut untuk mengoptimalkan penggunaan waktu efektifnya dalam memenuhi kebutuhan pengembangan semua domain. Akhirnya, program ini diyakini dapat memenuhi kebutuhan siswa berdasarkan fase pertumbuhan dan perkembangannya. Dari sinilah titik tolak dibangunnya suatu standar nasional untuk layanan bimbingan bagi semua siswa, termasuk di dalamnya ABA.

Secara empirik Program bimbingan sosial-pribadi berbasis model perkembangan telah menunjukkan bukti bahwa satu dekade yang lalu di USA (Iowa, 2001). Model ini merupakan suatu cara yang lebih disukai untuk mengorganisasikan dan mengelola program BK di sekolah, karena Model ini terutama telah mampu menunjukkan kontribusinya terhadap gerakan nasional dalam persoalan akuntabilitas di dalam menentukan hasil program pendidikan. Berdasarkan hasil riset yang dinyatakan oleh Schlossberg, Morris, 
dan Lieberman (2001) bahwa the counselor-led, developmental guidance that presented in high-school classroom has the potential to improve students' expressed behavior and general school attitudes, while addressing their developmental needs. Ini artinya bahwa bimbingan perkembangan yang diterapkan untuk SMA memiliki potensi untuk memperbaiki perilaku siswa dan sikap sekolah yang bersifat umum yang diperlukan untuk kebutuhan perkembangan.

Untuk sampai pada saat uji validasi yang mendapatkan penilaian "baik atau memadai", kiranya memerlukan suatu proses, baik itu yang berkenaan dengan penyiapan buku panduan, modul bimbingan sosial-pribadi, maupun keterampilan menerapkannya dalam proses bimbingan dengan pilihan tekniknya yang tepat. Secara subjektif, memang pada tahap uji validasi, implementasi dirasakan relatif lebih lancar dan memuaskan. Hal ini dapat juga disebabkan, uji validasi merupakan penerapan model yang ketiga kalinya, di samping materi modul latihan lembaran kerjanya lebih baik dan sesuai dengan kebutuhan ABA, juga teknik yang digunakannya lebih mengena dan tepat. Dengan kata lain, untuk penerapan model program bimbingan sosial-pribadi ini, hampir setiap menggunakan modulnya, digunakan teknik latihan keterampilan hidup kelompok (group life-skills training). Penggunaan teknik ini ternyata memiliki kontribusi yang berarti, bahkan didukung oleh beberapa temuan, di antaranya Vernon, 1989; Brake \& Gerler, 1994, Haines, 1994; Johnson \& Johnson, 1995; dan Lindsay, 1998 (Iowa State, 2001) yang menyatakan bahwa "small group social skill training is an effective intervention with students at all levels of development.... Group counseling is effective with high school students in learning effective stress reducing skills, instructing conflict resolution training.... Dengan demikian, dapat dipahami bahwa teknik bimbingan kelompok di samping secara substansial bermakna dalam pengembangan kecakapan hidup, juga secara ekonomis memiliki efisiensi yang tinggi, dan secara praktis dapat meningkatkan keterampilan sosial, respek terhadap orang lain dan perilaku kooperatif.

\section{EFEKTIVITAS P R O G R A M BIM- BINGAN SOSIAL-PRIBADI BERBA- SIS MODEL PERKEMBANGAN TER- HADAP PENINGKATAN KECAKAP- AN SOSIAL-PRIBADI}

Dalam penelitian ini diperoleh hasil bahwa program bimbingan sosial-pribadi berbasis model perkembangan secara empirik memiliki efek yang sangat berarti terhadap peningkatan kecakapan sosial-pribadi ABA. Pada hakikatnya, kecakapan sosial-pribadi setiap indivi$\mathrm{du}$ itu berkembang seiring dengan tugas perkembangannya. Setiap individu mengalami kemajuan kecakapan sosialpribadi menunjukkan kecepatan yang berbeda-beda sebagaimana dikatakan Adler (Capuzzi and Gross, 1995) bahwa life-style is unique. Life-style yang dimaksudkan di sini adalah gaya hidup setiap individu. Life-style itu dibangun secara interaktif antara keturunan dan lingkungan. Artinya, setiap individu untuk dapat mencapai bentuk tertentu, tidak cukup hanya mengandalkan keturunan 
saja, melainkan juga dapat memanfaatkan lingkungan yang dapat mendukung dalam proses pencapaian tujuan tersebut.

Dalam konteks ini, ABA juga demikian,kecakapansosial-pribadi pada tingkat tertentu diyakini dapat mendukung kebahagiaan hidupnya, yang tidak hanya di dunia, melainkan juga di akhirat. Untuk mencapai itu sangatlah membutuhkan sentuhan upaya yang sistematis, efektif, dan strategis. Berdasarkan bukti empirik bahwa antara kelompok kontrol dan kelompok eksperimen ternyata menunjukkan perbedaan yang berarti, yang lebih jelasnya bahwa kelompokeksperimen menunjukkan kenaikan tingkat kecakapan sosial-pribadi secara sangat berarti, tetapi kelompok kontrol tidak menunjukkan perubahannya yang berarti.

\section{KESIMPULAN}

Berdasarkan hasil analisis data, dapat dirumuskan kesimpulan sebagai berikut.

- Penelitian ini telah menghasilkan tiga jenis produk penelitian, yaitu: (a) perangkat instrumen inventori kecakapan sosial-pribadi yang sudah dibakukan dengan koefisien validitasnya $\mathrm{p}<0,01$ sebanyak 117 item dan $\mathrm{p}<0,05$ sebanyak 113 item; koefisien

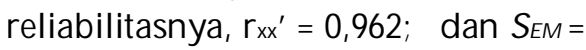
9; (b) temuan yang menunjukkan bahwa program bimbingan sosialpribadi berbasis model perkembangan secara sangat signifikan mampu meningkatkan kecakapan sosial-pribadi ABA yang dikuatkan dengan adanya perbedaan yang sangat signifikan antara hasil pre-test dan post- test kelompok eksperimen dengan $\mathrm{t}=$ $-6,191, \mathrm{dk}=45$ pada $\mathrm{p}=0,00)$, perbedaan yang tidak signifikan antara hasil pre-test dan post-test kelompok kontrol dengan $\mathrm{t}=-2,595, \mathrm{dk}=45$ pada $\mathrm{p}>0,01)$, dan diyakinkan dengan perolehan (gains) yang didapatkandalam kelompok perlakuan (treatment group) $=43,055$ yang jauh lebih tinggi daripada perolehan (gains) yang didapatkan oleh kelompok kontrol (control group) $=4,805$; dan diperolehnya pedoman umum pengembangan program bimbingan sosialpribadi berbasis model perkembangan yang dikuatkan dengan validasi terhadap materi program bimbingan oleh konselor dan impmentasi program bimbingan oleh ABA.

- Inventori yang digunakan untuk mengukur kecakapan sosial-pribadi menunjukkan validitas dan reliabilitas yang sangat tinggi, baik secara konseptual melalui judgment para ahli yang relevan, metodologi, dan bahasa, maupun secara empirik melalui ujicoba. Memang ujicoba ini tidak dilakukan terhadap ABA yang mengikuti program akselerasi, namun subjek yang dijadikan uji coba adalah siswa di sekolah favorit. Pemilihan strategi ini didasarkan atas keyakinan bahwa subjek dapat digolongkan sebagai anak yang memiliki potensi "unggul" yang tidak jauh dari ABA peserta program akselerasi.

- Program bimbingan sosial-pribadi berbasis model perkembangan merupakan suatu alternatif yang efektif untuk meningkatkan kecakapan sosial-pribadi ABA yang tidak hanya didukung oleh kualitas modul atau 
materinyaberdasarkan penilaian konselor, melainkan juga kinerjanya, baik yang terkait dengan aktivitas bimbingan, maupun kinerja konselornya berdasarkan penilaian stakeholders utamanya (ABA) dengan menunjukkan katagori baik, bahkan baik sekali.

- Program bimbingan sosial-pribadi berbasis model perkembangan secara empirik memiliki efek yang sangat berarti terhadap peningkatan kecakapan sosial-pribadi ABA. Artinya, penerapan yang tepat program bimbingan sosial-pribadi berbasis model perkembangan mampu memberikan kontribusi dalam meningkatkan berbagai kecakapan sosial-pribadi ABA yang sangat dibutuhkannya dalam menuju kehidupan yang mandiri dan memasuki kehidupan bermasyarakat.

\section{UCAPAN TERIMA KASIH}

Akhirnya, disadari bahwa tulisan ini tidak akan dapat diselesaikan tanpa adanya bantuan dari berbagai pihak, terutama peserta didik yang mengikuti program akselerasi, para konselor (guru BK), para guru, para kepala sekolah, para ahli, serta pihak-pihak lain yang berkontribusi bagi penyelesaian studi dan artikel ini, termasuk Dewan Redaksi Cakrawala Pendidikan (Jurnal Ilmiah Pendidikan). Semoga semua itu menjadi amal kebajikan dan mendapatkan pahala dari Allah swt. Amien.

\section{DAFTAR PUSTAKA}

Borg, Walter R. and Gall, Meredith D. 198. Educational Research: An Introduction. Fifth Edition. New York and London : Longman.

Bowers, Judy L. and Hatch, Patricia A. 2002. The National Model for School Counseling Programs. USA: ASCA.

Capuzzi, David and Gross, Douglas R. 1995. Counseling and Psychotherapy: Theories and Interventions. Englewood Cliffs, New Jersey: Merrill.

Colangelo, N, and Davis, Gary Al. 1991. Handbook of Gifted Education. Massachusetts: Allyn and Bacon.

Davis, Gary A. and Rimm, Sylvia B. 1989. Education of the Gifted and Talented, Second Edition. Boston: Allyn and Bacon.

Kitano, Margie K. and Kirby, Darrell F. 1986. Gifted Education: A Comprehensive View. Boston: Little, Brown and Company.

Milgram, Roberta M. 1991. Counseling Gifted and Talented Childre: A Guide for Teachers, Counselors, and Parents. New Jersey: Ablex Publishig Coorporation.

Piirto, Jane. 1994. Talented Children and Adults: Their Development and Education. Toronto: Maxwell Macmillan. 
Schlossberg, Sharon M., Morris, John D., and Lieberman, Mary G. 2001. "The Effects of Counselor LedGuidance Intervention on Students' Behaviors and Attitudes". in ERIC \# EJ630575 or Professional School Counseling, v4 n3 p156-64.

State of Iowa. 2001. Iowa Comprehensive Counseling and Guidance Program Development Guide, Iowa: Department of Education.

Silverman, Linda Keger. 1993. Counseling the Gifted and Talented. Denver: Love Publishing Company. 